\title{
Establishing Solar Water Disinfection as a water treatment method at household level
}

Regula Meierhofer

\section{ABSTRACT}

1.1 billion People worldwide do not have access to safe drinking water and therefore are exposed to a high risk for diarrhoeal diseases. As a consequence, about 6,000 children die each day of dehydration due to diarrhoea. Adequate water treatment methods and safe storage of drinking water, combined with hygiene promotion, are required to prevent the population without access to safe drinking water from illness and death.

Solar water disinfection (SODIS) is a new water treatment to be applied at household level with a great potential to reduce diarrhoea incidence of users. The method is very simple and the only resources required for its application are transparent PET plastic bottles (or glass bottles) and sufficient sunlight: microbiologically contaminated water is filled into the bottles and exposed to the full sunlight for 6 hours. During solar exposure, the diarrhoea causing pathogens are killed by the UV-A radiation of the sunlight.

At present, SODIS is used by about 2 Million users in more than 20 countries of the South. Diarrhoea incidence of users significantly has been reduced by 30 to $70 \%$. A careful and long-term community education process that involves creating awareness on the importance of treating drinking water and initiates behaviour change is required to establish the sustainable practice of SODIS at community level.

In Madagascar, more than 160 children younger than 5 years die each day from malaria, diarrhoea and acute respiratory illnesses. The application of household water treatment methods such as SODIS significantly could contribute to improve their health.

\section{THE NEED FOR WATER TREATMENT}

Water in sufficient quantity and good quality is essential for live. However, at the beginning of the year 2000 one sixth of the world's population, 1.1 billion people is without access to improved water supply and many more are without access to safe water (Unicef, 2000). The water quality in improved water supply systems often suffers from unreliable operation and lack of maintenance, or the water is subject to secondary contamination during collection, transport and storage.

The lack of access to good quality drinking water leads to a high risk for waterborne diseases such as diarrhoea, cholera, typhoid fever, hepatitis A, amoebic and bacillary dysentery and other diarrhoeal diseases. Each year 4 billion cases of diarrhoea
Swiss Fed. Institute of Aquatic Science and Technology (EAWAG) Dept. of Water and Sanitation in Developing Countries (SANDEC) Ueberlandstrasse 133

$\mathrm{CH}-8600$ Duebendorf

Switzerland

E-mail: regula.meierhofer@eawag.ch

cause 2.2 million deaths, mostly among children under the age of five (WHO, 2000). This is equivalent to one child dying every 15 seconds, or 20 jumbo jets crashing every day.

The public health condition in developing countries can abruptly change to the dramatic circumstances of spreading epidemics. Cholera for example remains a danger for such an epidemic outbreak. It is endemic in 80 countries and still a concern to all regions of the world. The number of deaths caused by cholera has declined over the last decades due to the application of simple and adequate curative treatment methods (oral rehydration therapy). Adequate water treatment methods and avoidance of secondary contamination of drinking water, combined with hygiene promotion, are required to prevent the population without access to safe drinking water from illness and death.

The simple act of washing hands with soap and water can reduce diarrhoeal disease transmission by one third (Unicef, 2000) (Figure 1). Promotion of household centred water treatment methods should therefore always be combined with hygiene training. Three key hygiene behaviours are of greatest likely benefit:

- Hand washing with soap (or ash or other aid)

- safe disposal of faeces

- safe water handling and storage (Unicef, 2000).

Thus, incorporating water treatment, safe water storage and health education into a single program is more likely to have a positive long lasting effect on public health.

\section{FROM CENTRALISED SYSTEMS TO A HOUSE-HOLD CENTERED APPROACH}

Much effort has been placed in the past by governments in developing countries on the installation of sophisticated water treatment plants and public water supply systems especially in urban areas, while the rural population often has remained neglected.

The conventional water treatment plants and distribution systems however often fail to produce and distribute water safe for consumption. The lack of trained operators, reliable supply of chemicals and spare parts, as well as financial constraints, often hinders a reliable operation and maintenance of the system. Water shortages lead to interruptions in the supply and leaky distribution systems worsen the situation. In addition, the rapid population growth in urban areas puts an excessive stress on the existing water and sanitation infrastructures and creates enormous problems in the planning and construction of new infrastructure. 


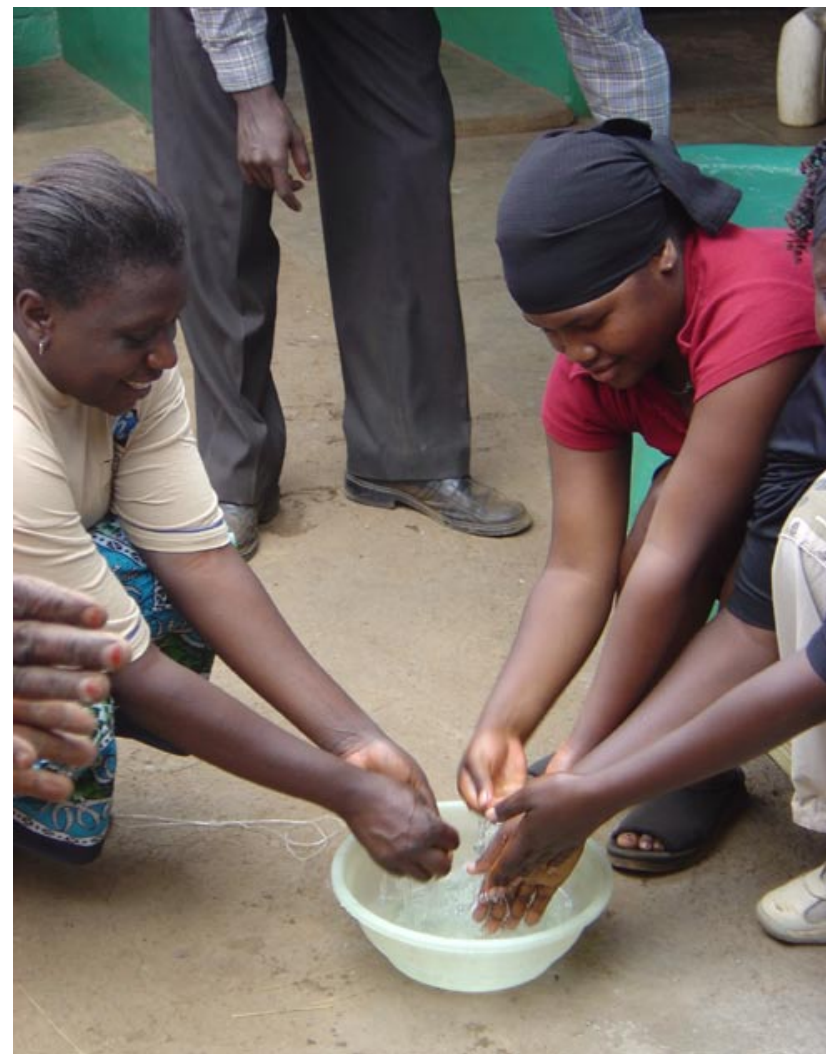

FIGURE 1. Washing hands with soap and water can reduce diarrhoea incidence by $30 \%$

Inhabitants of many urban centres in developing countries as well as the rural population therefore only have access to water of dubious quality. The treatment of water to be safe for consumption therewith often remains under the responsibility of the individual household (Mintz et al. 2001).

The following water treatment methods for the application at household level generally are recommended (WHO, 1997) to reduce feacal contamination of drinking water:

WATER STORAGE at household level is a simple method

to improve the water quality. Plain sedimentation however can only partly remove turbidity and faecal coliforms - the common indicator used to quantify the degree of feacal pollution. Therefore, water storage is only used as pretreatment for surface waters.

BOILING OF WATER is the safest water treatment method, it

kills all the microorganisms present in contaminated water Water should be brought to a rolling boil for one minute at sea level, adding one minute for everyadditional 1,000 metersinaltitude. The main disadvantage of boiling water is the large amount of energy required, which makes it relatively expensive and unaffordable for the poorest section of the population in developing countries. During decades development organisations have invested their efforts and resources to disseminate the information on the importance of boiling drinking water to communities without access to safe drinking water. To a large degree these efforts have not reached the targets or completely failed to achieve the intended behaviour change. This is not surprising, if we keep in mind that the cost for additional energy to boil the water often reaches 20 to $30 \%$ of the total household budget of poor families. Even if awareness for the importance of treating drinking water is there - who can afford to boil it?
WATER PASTEURISATION achieves the same effect

as boiling at temperatures of only $70^{\circ} \mathrm{C}-75^{\circ} \mathrm{C}$, but requires a longer exposure time of approximately 10 Minutes. Also pasteurisation requires much energy.

WATER FILTRATION by simple household filters,

such as ceramic candle filters, stone and sand filters, will remove a high fraction of solid matter, but may not remove all the microorganisms. Commercially produced filters are relatively costly, and filters made of locally available material are generally of limited treatment efficiency with regard to microbiological water quality improvement.

WATER DISINFECTION WITH CHLORINE is used to kill

microorganisms (bacteria and viruses), but it's efficiency to inactivate pathogenic parasites (e.g. Giardia, Cryptosporidium and helminth eggs) depends on different factors (e.g. free $\mathrm{Cl}$, $\mathrm{pH}$, temperature, contact time). Water treated with chlorine is protected against recontamination. This type of treatment requires the supply of chlorine either in liquid or powder form. skilled application is necessary as chlorine is a hazardous and corrosive substance. Water treated by chlorine has a taste which many users do not appreciate.

SOLAR WATER DISINFECTION (SODIS) is a simple water treatment method using solar radiation (UV-A light and temperature) to destroy pathogenic bacteria, viruses as well as Cryptosporidium spp. and Giardia spp. present in the water. A great advantage of SODIS is that it uses locally available resources such as transparent PET-plastic bottles (or glass bottles) and sunlight. Therefore SODIS can be replicated with very low cost.

\section{HOW DOES SODIS WORK?}

Contaminated water is filled into transparent plastic bottles, preferably PET-bottles, and exposed to the full sunlight for 6 hours. During the exposition, the sunlight destroys the pathogenic bacteria, viruses as well as Cryptosporidium spp. and Giardia spp (Wegelin et al. 1994; Mendez-Hermida et al. 2005; McGuigan et al. 2006). The destruction of parasites is caused by the UV-A radiation of the sunlight. Laboratory tests as well as field research in Bolivia and Nepal have shown that the water is also disinfected if SODIS is applied in cooler climatic areas and if the water temperature in the bottle remains below $40^{\circ} \mathrm{C}$. However, a synergy of UV-A radiation and temperature occurs if the water temperature raises above $50^{\circ} \mathrm{C}$, then the disinfection process only requires a third of the solar radiation intensity. After one hour of solar exposition at $50^{\circ} \mathrm{C}$, the water is safe for consumption (Wegelin et al. 1994). SODIS is highly efficient to improve the microbiological water quality at household level, but it cannot always guarantee a $100 \%$ reduction rate of pathogens as the SODIS efficiency depends on climatic conditions and the user's handling practices.

Factors to be considered during the application of SODIS:

CLIMATIC CONDITIONS: The effect of SODIS is depend

ent on the availability of sufficient sunlight. The solar radiation intensity required of $2500 \mathrm{Wh} / \mathrm{m}^{2}$ is well reached within 6 hours of solar exposure on a sunny or partially cloudy day in countries between latitude $35^{\circ} \mathrm{N}$ and $35^{\circ} \mathrm{S}$. During days of partial rainfall, strong clouds or fog, the bottles have to be exposed for 2 consecutive days to disinfect the water. During days of continuous rainfall, boiled water or stored SODIS water should be consumed (Wegelin et al. 1994). 


\begin{tabular}{|c|c|c|}
\hline Pathogen & Illness & $\begin{array}{l}\text { Reduction through SODIS ** } \\
\text { at water temperatures of } 40^{\circ} \mathrm{C} \text { and solar } \\
\text { exposure of } 6 \text { hours }\end{array}$ \\
\hline \multicolumn{3}{|l|}{ Bakteria } \\
\hline E.coli & $\begin{array}{c}\text { Indikator for Water } \\
\text { Quality } \\
\text { \& Enteritis }\end{array}$ & $\begin{array}{c}3-4 \log \\
(99.9-99.99 \%)\end{array}$ \\
\hline Vibrio cholera & Cholera & $3-4 \log$ \\
\hline Salmonella spp. & Thyphoid & $3-4 \log$ \\
\hline Shigella spp. & Dysentery & $3-4 \log$ \\
\hline \multicolumn{3}{|l|}{ Viruses } \\
\hline Rotavirus & Diarrhoea, Dysentery & $3-4 \log$ \\
\hline Polio Virus & Polio & $\begin{array}{c}\text { inactivated, results not yet } \\
\text { published }\end{array}$ \\
\hline Hepatitis Virus & Hepatitis & $\begin{array}{c}\text { Reduction of cases of SODIS } \\
\text { users }\end{array}$ \\
\hline \multicolumn{3}{|l|}{ Protozoa } \\
\hline Giardia spp & Giardiasis & 3-4 log (Infectivity of Cysts) \\
\hline Cryptosporidium spp. & Cryptosporidiasis & 2-3 log (Infectivity of Cysts) \\
\hline
\end{tabular}

FIGURE 2. The following pathogens are destroyed by SODIS (Wegelin 1994, Sommer 1997, McGuigan 1998, Kehoe 2004, Méndez-Hermida 2005, Lonnen 2005, McGuigan 2006)

TURBIDITY: SODIS requires relatively clear water with a

turbidity of less than 30 NTU (Nephelometric Turbidity Units) to be effective (Wegelin et al. 1994). A simple test is available to check if water is clear enough for the application of SODIS: Place the open bottle upright onto the SODIS Logo or the headline of a newspaper. Look through the mouth of the bottle through the bottles toward the Logo or the newspaper. The water is clear enough for the SODIS application if you still can read the headline of the newspaper (Figure 3A and 3B).

If the water is too turbid for the application of SODIS, the water needs to be treated before it can be filled into the bottles:

Methods to remove turbidity:

- let the bottles stand for a while until the particles settle to the ground

- filter the water through a folded cloth

- use alum or the crushed seed of Moringa olifeira for flocculation and sedimentation

BOTTLES: SODIS requires transparent containers, which

transmit UV-A-light. Most suitable are plastic bottles made from PET, but also glass bottles can be used if they have a lid that can be closed again. Users in developing countries prefer to use PET-bottles because they are cheaper than glass, they can be carried around more easily and they do not break easily. Old and scratched plastic bottles should be replaced after about 6 to 12 months of regular daily use for SODIS as the mechanical scratches and photo-oxidation of the material reduce its transmission of UV-light. The depth of the container should not exceed $10 \mathrm{~cm}$ as at this depth, and at a turbidity level of 26 NTU, the UV-A radiation is reduced to $50 \%$. This means, that the volume of bottles to be used for SODIS should not exceed 2 litres.

OXYGEN: SODIS is more efficient in water containing high levels of oxygen: In water sunlight produces highly reactive forms of oxygen (oxygen free radicals and hydrogen peroxides) which react with the microorganisms' cell components. Aeration of the water can be achieved by shaking the $3 / 4$ filled bottles for about 20 seconds before they are filled completely (Reed, 1997).

THE HEALTH EFFECT IN COMMUNITIES USING SODIS The effect of consuming SODIS treated water on the health was first examined in Kenya in the 90ies. The study examined Kenyan children under 5 years and found a $16 \%-24 \%$ of diarrhoea reduction among Maasai children below 5 and a $86 \%$ reduction of cholera cases during an outbreak (Conroy et al. 1996, 99, 01). During the years 2000 to 2003 the Swiss Tropical Institute in collaboration with EAWAG conducted an epidemiological study to assess the health impact of SODIS on more than 200 children below 5 in Bolivia. The study showed that SODIS reduced the diarrhoea incidence by more than $35 \%$ (Hobbins, 2003). Further health evaluation studies were conducted in the two cities Rajoa and Chinot in Pakistan 2002, where diarrhoea incidence was reduced from $26 \%$ to $13 \%$ in Rajoa and from $39 \%$ to $19 \%$ in Chiniot and in Uzbekistan in 2003, where children $<5$ showed a reduction of diarrhoea incidence by $53 \%$. In the control group the occurrence of diarrhoea illnesses increased. Also in Nepal, East Lombok and Assam, India, the diarrhoea incidence was reduced by 50 to $70 \%$ (unpublished project reports).

\section{GLOBAL PROMOTION OF SODIS}

EAWAG/SANDEC initiated the promotion and dissemination of SODIS in 1995 with seven pilot projects in Latin America, Africa and Asia. Following the positive results in the pilot projects, the SODIS promotion and dissemination process has been initiated at national level in more than 20 developing countries. "Fundación SODIS" in Latin America and the SOLAQUA Foundation in Asia 


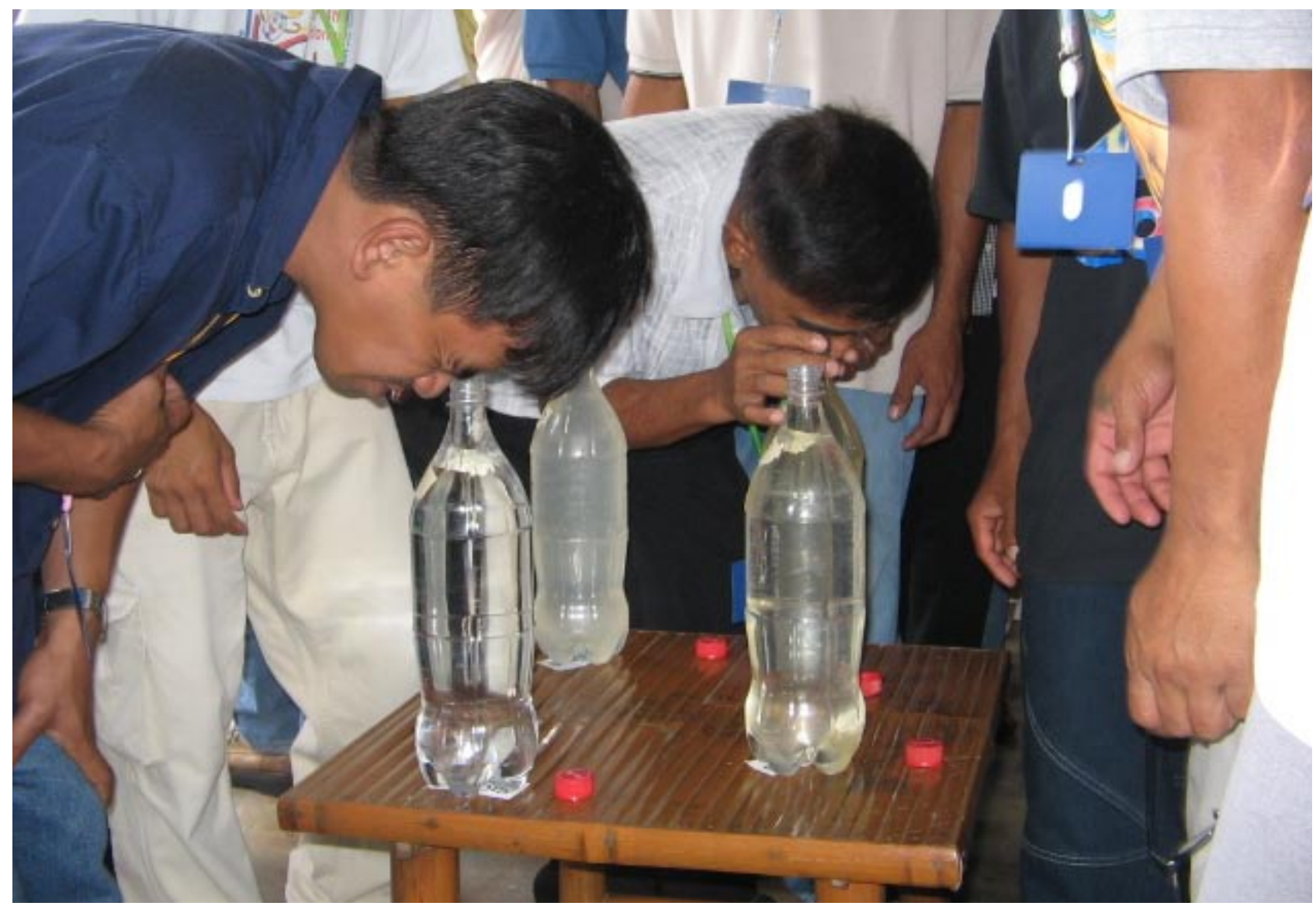

FIGURE 3A. A simple test can be applied to test the turbidity of water

and Africa support the SODIS dissemination process through information campaigns, training and advising of government institutions, networking activities as well as awareness building and training of users at grassroots level. As a result of these activities about 2 Million people presently use SODIS for the treatment of their drinking water.

In Madagascar, only about 3 out of 10 people have access to improved water supply and sanitation, even less have access to safe drinking water. As a consequence, more than 160 children die each day in Madagascar before their fifth birthday from malaria, diarrhoea and acute respiratory illnesses (Unicef, country reports). The promotion and dissemination of household water treatment methods such as for example SODIS significantly could contribute to improve the health of the local population, particularly of children below 5 years.

The socio-cultural acceptance of SODIS was evaluated during the pilot projects as well as during project implementation in Nicaragua and Bolivia. The assessments showed that the sustainable uptake of the method depends on the promotion approach and lies between $40 \%$ and $80 \%$ of the people trained.

At international level, SODIS is in the process of reaching global recognition. On the World Water Day on 22 March 2001 WHO recommended SODIS as one of the measures to reduce health hazards related to drinking water. SODIS is a member of WHO's 2003 established international network for the promotion of household water treatment and safe storage (http://www.who.int/household_water/en/). In recognition of these achievements, SODIS received the special price of the

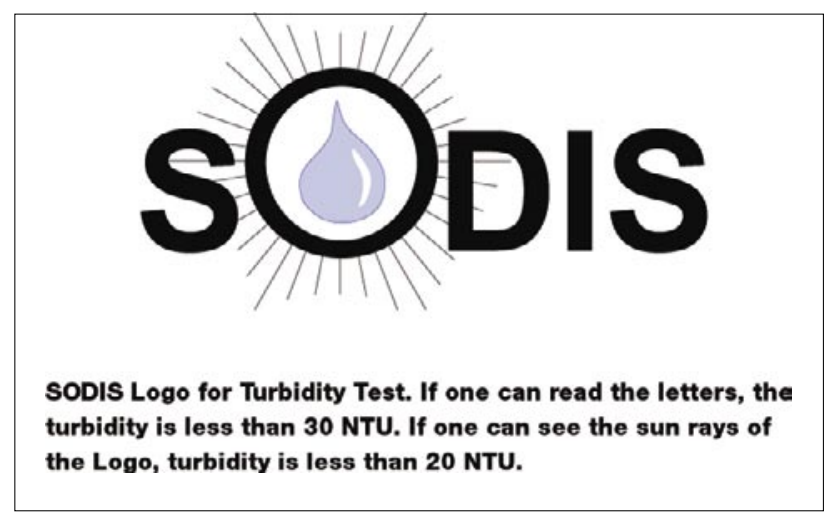

FIGURE 3B SODIS Logo for turbidity.

Energy Globe Award 2004, a most prestigious environmental price www.energyglobe.at.

\section{DISSEMINATION OF SODIS AT GRASSROOTS LEVEL}

Before a SODIS project in a specific area is planned and implemented, a needs assessment should be conducted to get the critical information on the environmental conditions in a specific area and insight into current behaviour practices of the local population. The assessment will provide information about the characteristics of the population, health status of the community, diarrhoea incidence, the water sources, water consumption and treatment practices, healthy habits and unhygienic behaviours.

The needs assessment does provide the basic information for the decision whether a SODIS project makes sense and should be implemented or not. A SODIS project should not be implemented if: 


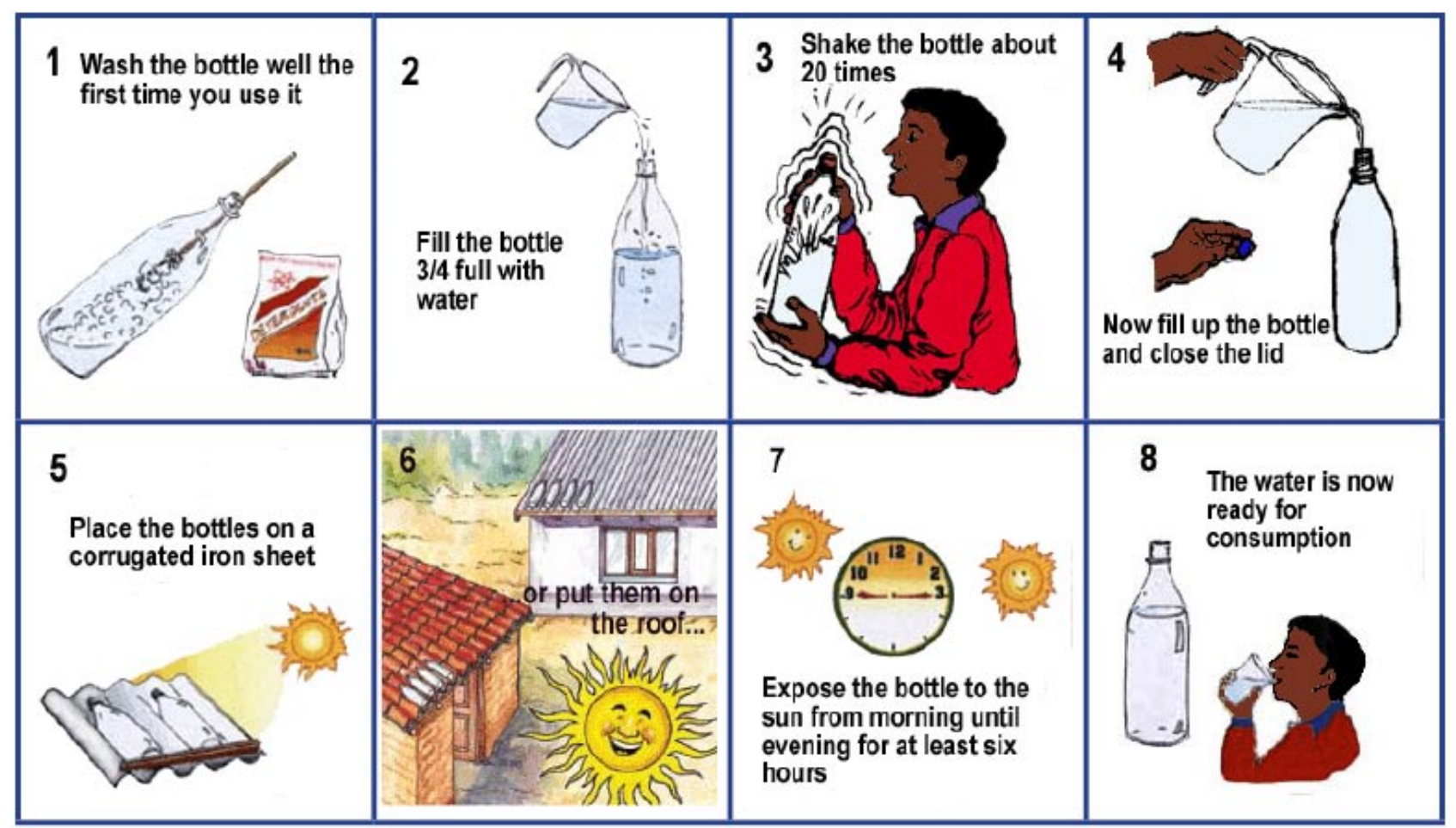

FIGURE 4. Steps required for the application of SODIS

- people consume clean drinking water

- people do not suffer from diarrhoeal diseases

- people successfully use another method for the disinfection of drinking water

- climatic conditions do not favour the application of SODIS

- PET bottles are not available and a supply scheme cannot be established

A SODIS education project will highly benefit the health of people if they consume microbiologically contaminated water, suffer from a high diarrhoea incidence and if PET-bottles are available locally.

A very careful community education approach is required in order to establish SODIS at grassroots level. It is not easy to create an understanding among illiterate people on the relation between the consumption of contaminated drinking water, hygiene practices and the effect of invisible pathogens on human health. The awareness on the importance of treating water before the consumption and adequate hygiene practices such as washing hand with soap however needs to be established before people will use a water treatment method such as SODIS. Such processes for changing habits and establishing new behaviours require much time and intensive coaching from community workers

Experiences made during the implementation of SODIS activities at the field level revealed the importance of the following points:

- Isolated information events do not establish SODIS practice in the community. Long-term education processes are required which involve participatory tools for hygiene education and careful coaching through community workers at community gatherings. Regular household visits (once a month during 6 to 12 months) are an important factor for achieving behaviour change.

- The trust and strong relation between the field staff and the community is a key aspect for the success of the project. The adoption of SODIS in the community is enhanced if field staff has a close relation with the people. Also, it is very effective to spread and promote the method at grass roots level through local leaders, for example health promoters, teachers or other locally respected persons.

- The field staff has to personally use SODIS, and therewith demonstrate the confidence in SODIS.

- SODIS is a simple method, but it needs careful training. Trainers must be experienced in the application of SODIS. if the treatment procedures are not followed correctly, the users fail to produce water safe for consumption.

- Good quality SODIS training and promotion material plays a significant role in the implementation process.

- Demonstrations of the effectiveness of SODIS at the field level do reduce scepticism: To demonstrate the effect of SODIS by performing water quality tests of raw water and SODIS treated water in front of the community can be a good tool to overcome doubts.

- A good approach is to integrate SoDIS into already existing projects working in the field of community health \& hygiene education.

- The local availability of the material needed is crucial for the sustainability of the SODIS application. If no plastic bottles are available locally, a supply scheme needs to be established for the purchase and transport of used plastic bottles from the city to the villages.

\section{REFERENCES}

CCONROY R.M., ELMORE-MEEGAN M., JOYCE T.M., MCGUIGAN K.G., BARNES J. 1996. Solar disinfection of drinking water and diarrhoea in Maasai children: a controlled field trial. The LANCET, Vol. 348

CONROY R.M., ELMORE-MEEGAN M., JOYCE T.M., MCGUIGAN K.G., BARNES J. 1999. Solar disinfection of water reduces diarrhoeal disease, an update, Arch Dis Child, Vol. 81

CONROY R.M., ELMORE-MEEGAN M., JOYCE T.M., MCGUIGAN K.G., BARNES J. 2001. Use of solar disinfection protects children under 6 years from cholera, Arch Dis Child, Vol. 85: 293-295 


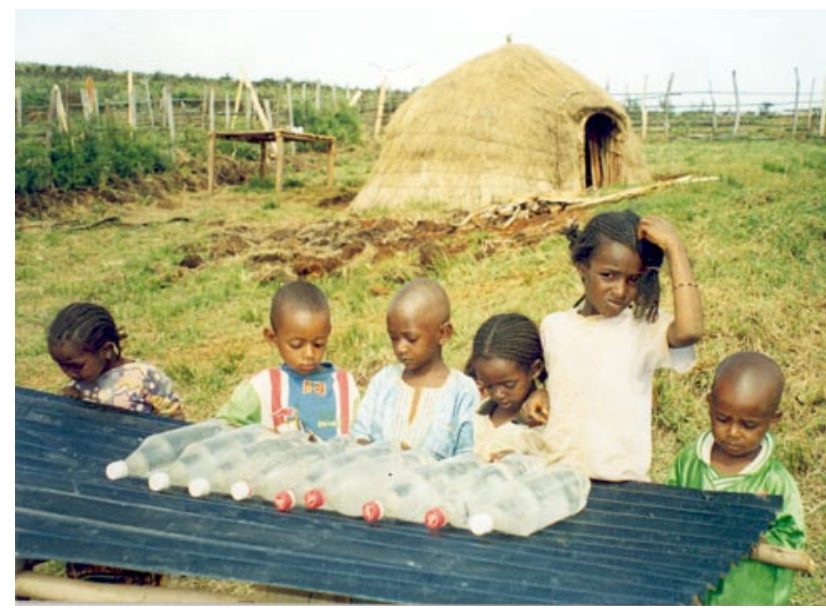

FIGURE 5. SODIS reduces the diarrhoea incidence of users, especially of children below 5 years.

HOBBINS M. 2003. The SODIS Health Impact Study, Ph.D. Thesis, Swiss Tropical Institute, Basel.

KEHOE S.C., BARER M.R., DEVLIN L.O., MCGUIGAN K.G. 2004. Batch process solar disinfection is an efficient means of disinfecting drinking water contaminated with Shigella dysenteriae Type I. Letters in Applied Microbiology, Vol. 38: 410-414

LONNEN J., KILVINGTON S., KEHOE S.C., AL-TOUATI F., MCGUIGAN K.G. 2005. Solar and photocatalytic disinfection of protozoan, fungal and bacterial microbes in drinking water. Water Research, Vol: 39: 877-883

MCGUIGAN K.G., JOYCE T.M., CONROY R.M., GILLESPIE J.B., ELMOREMEEGAN M. 1998. Solar disinfection of drinking water contained in transparent plastic bottles: characterizing the bacterial inactivation process. Journal of Applied Microbiology, Vol. 84: 1138-1148

MCGUIGAN K.G., MÉNDEZ-HERMIDA F., CASTRO-HERMIDA J.A., ARESMAZÁS E., KEHOE S.C., BOYLE M., SICHEL C., FERNÁNDEZ-IBÁÑEZ P., MEYER B.P., RAMALINGHAM S., MEYER E.A. 2006. Batch solar disinfection (SODIS) inactivates oocysts of Cryptosporidium parvum and cysts of Giardia muris in drinking water, J. Appl. Microbiol. In press.

MÉNDEZ-HERMIDA F., CASTRO-HERMIDA J.A., ARES-MAZÁS E., KEHOE S.C., MCGUIGAN K.G. 2005. Effect of batch-process solar disinfection on survival of Cryptosporidium parvum oocysts in drinking water. Appl. Env. Microbiology, Vol. 71, No. 3: 1653-1654

MINTZ E., BARTRAM J., LOCHERY P., WEGELIN M. 2001. Not just a drop in the bucket: expanding access to point-of-use water treatment systems. AJPH Oct.

REED R.H. 1997. Solar inactivation of faecal bacteria in water: the critical role of oxygen. Letters in Applied Microbiology, Vol. 24

SMITH R.J., KEHOE S.C., MCGUIGAN K.G., BARER M.R. 2000. Effects of simulated solar disinfection on infectivity of Salmonella typhimurium. Letters in Applied Microbiology, Vol. 31, Nr. 4: 284-288

SOMMER B., MARIÑO A., SOLARTE Y., SALAS M.L., DIEROLF C., VALIENTE C., MORA D., RECHSTEINER R., SETTER P., WIROJANAGUD W., AJARMEH H., AL-HASSAN A., WEGELIN M. 1997. SODIS-an emerging water treatment process. Journal of Water Supply: Research and Technology, Aqua, Vol. 46 , No. 3

UNICEF 2000. Global Water supply and Sanitation Assessment 2000 Report.

WEGELIN M., CANONICA S., ALDER A.C., MARAZUELA D., SUTER M., BUCHELI TH.D., HAEFLIGER O.P., ZENOBI R., MCGUIGAN K.G., KELLY M.T., IBRAHIM P., LARROQUE M. 2000. Does sunlight change the material and content of polyethylene terephtalate (PET) bottles? Journal of Water Supply: Research and Technology, Aqua, No. 1

WEGELIN M., CANONICA S., MECHSNER K., FLEISCHMANN T., PESARO F., METZLER A. 1994. Solar Water Disinfection: Scope of the Process and Analysis of Radiation Experiments, Journal of Water Supply: Research and Technology, Aqua, No. 4

WHO 1997. Guidelines for Drinking Water Quality. Vol.3, Geneva.

WHO 2000. The world health report: Making a difference. Geneva.

WHO 2001. Water for Health. Taking Charge. Geneva.

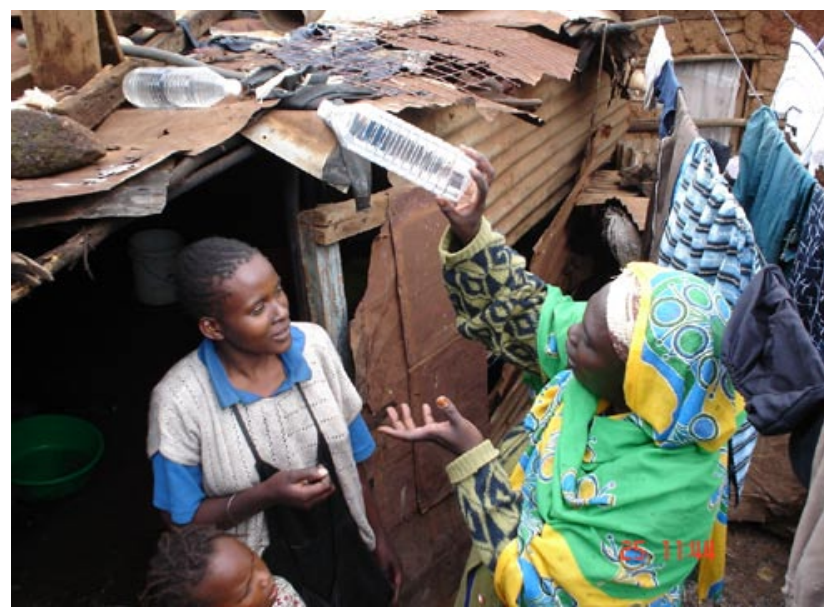

FIGURE 6. A relation of trust between community worker and users is important for establishing behaviour change.

\section{EDITORIAL NOTE}

\section{SWISS RED CROSS FEDERATION AWARD FOR SODIS}

Zurich, June 24, 2006

For the first time in its 140 years old history, the Swiss Red Cross (SRC) has awarded a price (25,000 CHF) for special humanitarian commitment. This price has been awarded to the SODIS project directed by Martin Wegelin, EAWAG/SANDEC. The SODIS project receives with this price additional publicity which is needed for the further promotion of this simple but effective water disinfection method used at household level. 